\title{
North Otago soils: physical properties and nutrient requirements for economic production
}

\author{
J.D. MORTON', A.H.C. ROBERTS ${ }^{2}$, D.C. EDMEADES ${ }^{2}$ and M.J. MANNIENG ${ }^{3}$ \\ ${ }^{1}$ AgResearch, Invermay, PB50034, Mosgiel \\ ${ }^{2}$ AgResearch, Ruakura, PB3123, Hamilton \\ ${ }^{3}$ Ravensdown Fertiliser, Box 452,Dunedin
}

\section{Abstract}

North Otago soils are all of sedimentary origin but range in topography from flat alluvial and terrace soils to hill soils. Most of the farmed soils are yellow-grey earths on the rolling downlands or plains. Yellow-grey earths on the downlands have dense subsoils that limit water movement during wet winters and rooting depth during dry summers. Plains soils have shallow depths to gravels limiting water holding capacity and making irrigation necessary for intensive pastoral production. The relationships between soil nutrient levels and pasture production has been shown to be of the diminishing returns type. Soil nutrient levels for near maximum pasture production on North Otago soils are Olsen P 20-25, sulphate-S 10-12, organic-S 15-20 and quick test K 5-8. At high stocking rates profitable responses in pasture and animal production can still be gained at higher Olsen P levels. The decision support nutrient model $\left(\right.$ OUTLOOK $\left.{ }^{\mathrm{TM}}\right)$ has been developed to help farmers apply fertiliser at optimum rates for economic production.

Keywords: economic production, North Otago, phosphorus, potassium, sedimentary soils, sulphur, yellow-grey earths

\section{Introduction}

Soils are formed by the combined effect of soil-forming factors (parent material, climate, time, topography, soil, living organisms), and the modifying effects of human activity plus a number of soil processes (e.g., leaching,

podzolisation, '̄ gleying, humification and biological disturbance). The resulting chemical and physical properties for some soils are better situated to modem farming practices than others. Most North Otago soils have been amended in some way to improve pastoral production (e.g., fertiliser addition, irrigation). The challenge for the future is to sustain profitable levels of production on these soils without adversely affecting the environment through nutrient and sediment loss to waterways.
In 1995, the North Otago Sustainable Land Management Group published a set of sustainable land management guidelines for the North Otago downlands, which included soil nutrient requirements. This paper will extend this to cover all North Otago soils.

Nutrient requirements for North Otago soils are determined by relating on-farm soil test results to the appropriate level of economic production for that farm. To achieve this the results from 400 soil fertility trials involving major nutrients have been collated into an electronic database by AgResearch scientists. Information from this has been used to develop farmer manuals on the principles and practice of fertiliser use (Morton et al. 1994; Roberts et al. 1994) and decision support nutrient models such as OUTLOOK ${ }^{\mathrm{TM}}$ (Metherell 1995). Apart from phosphorus (P), sulphur (S) and potassium $(\mathrm{K})$, trace elements are also required for pasture production $(\mathrm{Mo})$ and animal health $(\mathrm{Co}, \mathrm{Cu}$, $\mathrm{Se})$ on North Otago soils.

Soil physical properties are just as important as chemical properties in determining the pastoral production of a soil. There are considerable differences in physical properties between North Otago soils requiring different management for sustainable

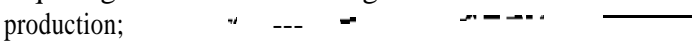

\section{Soils of N orth 0 tago}

In this paper, North Otago is defined as the land area bounded by the Waitaki River in the north, Moeraki in the south and Duntroon in the west. North Otago landforms are shown in Figure 1. The soils in this area occur as three major land forms: rolling downlands, plains and hills.

\section{Rolling downlands (65\% of area)}

Soils on rolling downs are formed from loess (yellowgrey earths), basaltic ash (brown granular clays) and limestone (rendzinas) under mean annual rainfall of 500 to $625 \mathrm{~mm}$. Yellow-grey earths are the major soils of the rolling downlands. The main yellow-grey earths are the Timaru, Opuha, Claremont, Ngapara, Wakanui and Kauru soils. Timaru, Opuha and Claremont soils have the most compacted subsoils (fragipans: dense silty horizon created through wetting and drying 
processes). Fragipins limit rooting depth and downward water movement. Under dryland conditions the slow drainage of excess water is only likely to be a problem with the Claremont and Opuha soils, as they are located in the higher rainfall areas. With irrigation care must be taken to ensure there is no over-watering, which is likely to cause temporary waterlogging and reduce pasture growth. The Ngapara and Wakanui soils contain less developed fragipans while the Kauru soils does not have a fragipan but the subsoil is tightly packed. Where the Wakanui soil is located in areas with high water tables, it can become saturated for long periods of time and irrigation should not be considered in such situations. All yellow-grey earths have similar plant available water capacity (15-20 $\mathrm{mm}$ per $100 \mathrm{~mm}$ soil depth).

Yellow-grey earths have poor soil structure because of high silt and fine sand content with low amounts of clay to bind them. Soil structure breaks down easily because organic matter content is low and soil particles are easily dispersed by water. Therefore excessive cultivation causes surface crusting after rain and puts the soil at risk to erosion by wind or water. Because the subsoil can easily disperse with water any subsoil operation (e.g., subsoiling or pipe installation) should be undertaken very carefully especially if the site is intensively irrigated. Yellow-grey earths are very susceptible to damage by compaction if grazed when wet owing to their low clay contents and unstable structure.

The main brown granular clay is the Waiareka soil This soil is markedly different from the yellow-grey earths. It has a high clay content and a very strongly developed structure. Although Waiareka soils are highly resilient, continuous cropping can result in low organic carbon levels, and massive pans in the lower topsoil. The Waiareka soil can be difficult to cultivate as there is a very narrow range of water content at which it can be successfully worked. Although plant available water is about the same as that of yellow-grey earths, the onset of drought conditions will often occur later. This is because roots can penetrate to considerable depths when the soil is moist, giving the plant better access to water deep in the subsoil.

Like the Waiareka soil, the main rendzina Oamaru soil has a well-developed structure. This allows intense cultivation without physical degradation, tolerance to compaction and good drainage characteristics. However, Oamaru soils are very susceptible to drought because of their shallow depth above limestone, restricting root depth and water holding capacity.

\section{Plains $(20 \%$ of area $)$}

Plains soils include yellow-grey earths on the terraces bordering river valleys and recent soils on the alluvial plains. Pukeuri soils formed from alluvium derived from
Figure 1 North Otago land forms.

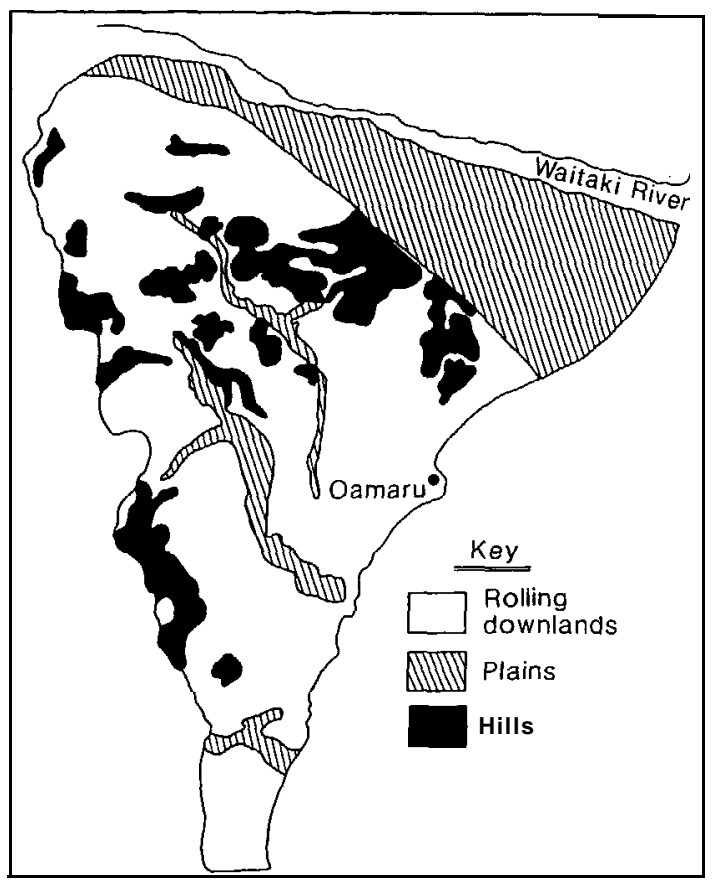

loess, marl and calcareous sandstones are present along the base of the rolling downlands in the Waitaki Valley. Drainage is adequate on gently undulating surfaces but impeded on the flatter surfaces. Soils dry out in summer. Steward soils occur on the Waitaki fans and are predominantly shallow, stony and porous. They have a cemented gravel pan that limits water movement. Recent soils include excessively drained Waimakariri sands, free-draining Paparua sands and moderately to welldrained Templeton silt loams. Water holding capacity varies from very low (Waimakariri soils) to moderate (Templeton soils).

\section{Hills $(15 \%$ of area $)$}

Hill soils are hilly phases of the yellow-grey earths (Kauru, Claremont, Timaru, Opuha), brown granular clays (Waiareka) and rendzinas (Oamaru) of the rolling downlands. In addition there are further yellow-grey earth hill soils on the eastern Kakanui range.

All these soils are moderately steep and liable to sheet and gully erosion. Drainage is moderate and the soils are subject to seasonal drought.

\section{Nutrient requirements for $\mathrm{N}$ orth $\mathrm{O}$ tago soils}

\section{Phosphorus}

There is a requirement for $\mathrm{P}$ on all North Otago soils. Nearly all of the farmed soils in North Otago can be 
classified as sedimentary soils. The exception is the Waiareka brown granular clay which has a higher $\mathrm{P}$ retention and is classified as a volcanic soil. Relevant trials conducted on sedimentary soils (YBE, YGE, YGE/ YBE, recent) from throughout New Zealand have been grouped together to determine the relationship between relative pasture production and Olsen $\mathrm{P}$ soil test (production functions e.g., Figure 2). The sedimentary soil groups have been combined because it was not possible to identify any differences in the relationship between soil Olsen $\mathrm{P}$ and relative yield for individual soil groups. Results from rates-of-P trials under sheep grazing and small plot mowing carried out in North Otago are included in the data used to derive this relationship. The soil Olsen $\mathrm{P}$ test that gives near maximum pasture production ( $97 \%$ RY) for sedimentary soils is 20 . Nevertheless the variability about the curve (as denoted by the $95 \%$ confidence intervals) means that there are still some increments in pasture production to be gained by achieving a higher soil Olsen P level. This could only be justified by a farming system that achieves high pasture utilisation such as intensive dairying at high stocking rates (greater than 3 cows/ha).

Figure 2 The relationship between relative pasture production and Olsen P test for sedimentary soils.

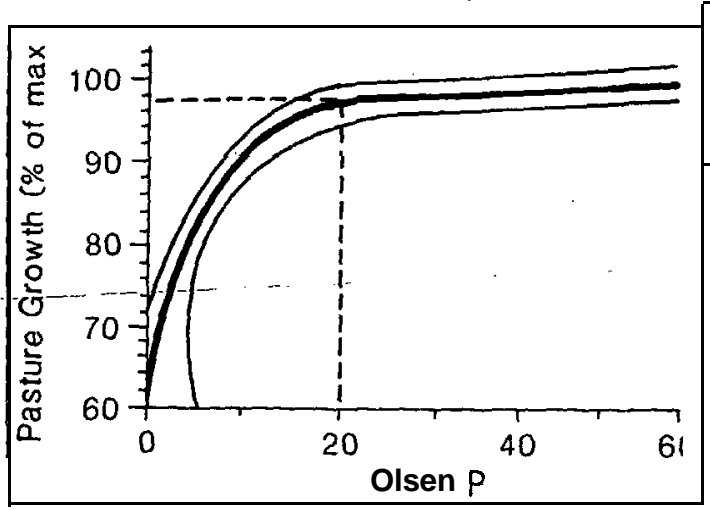

If the Olsen P status of the soil is below that required for optimum economic production (see later section) then large amounts (up to $100 \mathrm{~kg}$ P/ha) of soluble_P fertiliser (e.g., superphosphate) should be applied. Application of $5 \mathrm{~kg} \mathrm{P}$ ha (range $3-7 \mathrm{~kg} \mathrm{P} / \mathrm{ha}$ ) are'required over and above maintenance to increase the soil Olsen $\mathrm{P}$ level by one unit. Annual on-farm monitoring of soil Olsen P levels on dairy farms has shown increases of this order from the application of capital P.

\section{Sulphur}

Sulphur is required on all North Otago soils, especially rendzinas and the drier yellow-grey earths. Two soil tests are used to assess the $\mathrm{S}$ status of soils: the sulphate-S test (Saunders et al. 1981) used to measure immediately available $\mathrm{S}$ and the extractable organic $\mathrm{S}$ test (Watkinson et al. 1991), which measures more slowly available $\mathrm{S}$. Research results show that there are universal relationships between relative pasture yield and the two $\mathrm{S}$ tests for all soil groups (Figures 3 and 4). To achieve near maximum pasture production, sulphate-S levels of JO-12 and organic-S levels of 1520 are required.

Figure 3 The relationship between relative pasture production and soil sulphate-S.

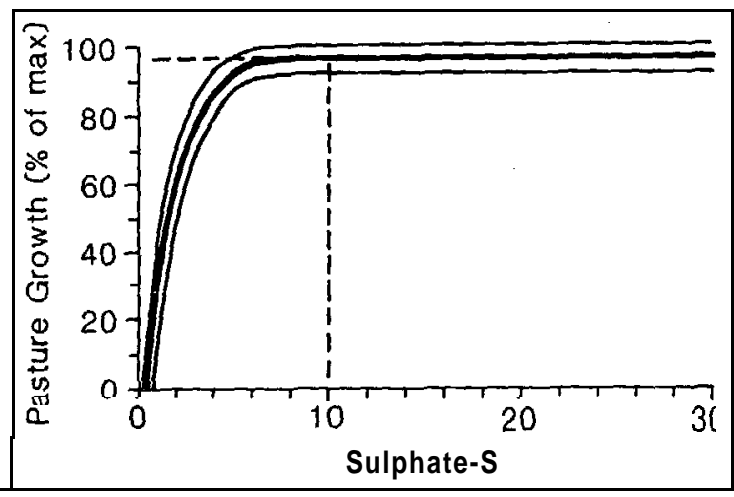

Figure 4 The relationship between relative pasture production and soil organic-S.

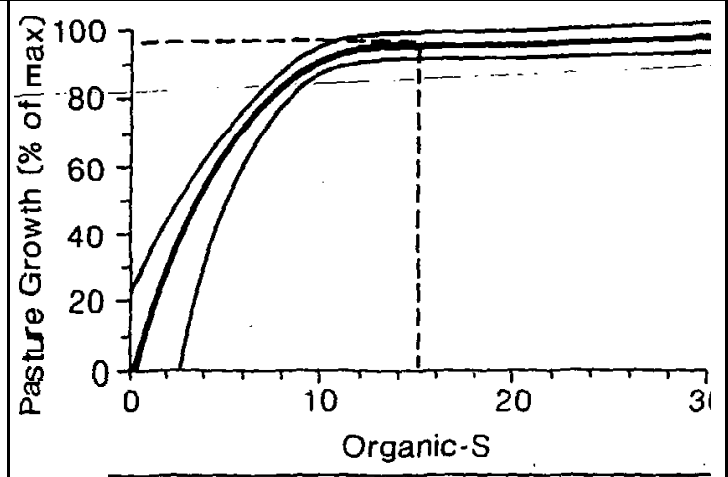

In practice sulphate-S levels vary widely during the year, depending on timing of $\mathrm{S}$ fertiliser, rainfall and temperature. In contrast organic-S levels are more stable, increasing slowly with duration of pasture development. Organic $\mathbf{S}$ represents the reserve of S present in the soil for pasture growth. If low (less than 5) then it is essential that an effective $\mathrm{S}$ fertiliser policy is used.

Field trial results (including North Otago trials) shown that $\mathrm{S}$ deficiencies may be overcome by applying 
$35 \mathrm{~kg} \mathrm{~S} / \mathrm{ha} /$ year (range 30-40), provided that the appropriate form of $\mathrm{S}$ and timing of application are used. Results from the $S$ database show that elemental $S$ is more effective in the autumn than spring (Thorrold pers. comm.). Earlier research has demonstrated that on most North Otago soils, a large proportion of the elemental $\mathbf{S}$ must have a particle size less than $0.15 \mathrm{~mm}$ to be effective when applied annually.

\section{Potassium}

The two soil tests used to assess the potassium status of North Otago soils are quick test K (Cornforth 1980) for immediately plant available $\mathrm{K}$ and the sodium tetraphenylboron-extractable $\mathrm{K}$ (TBK) soil test (Jackson 1985) for reserve K. Most North Otago soils (yellowgrey earths, recent) supply plant-available $\mathrm{K}$ at a slow rate through continual weathering of soil clay minerals, and this is measured by the TBK test.

The relationship between quick test $\mathrm{K}$ and relative pasture production (Figure 5) shows that a level of 6 (range 5-8) is required for near maximum pasture production. Limited datasuggest that near maximum pasture production was obtained at a TBK value of 0.8 me. $\%$.

Figure $\mathbf{5}$ The relationship between relative pasture production and soil test $\mathrm{K}$ for sedimentary soils.

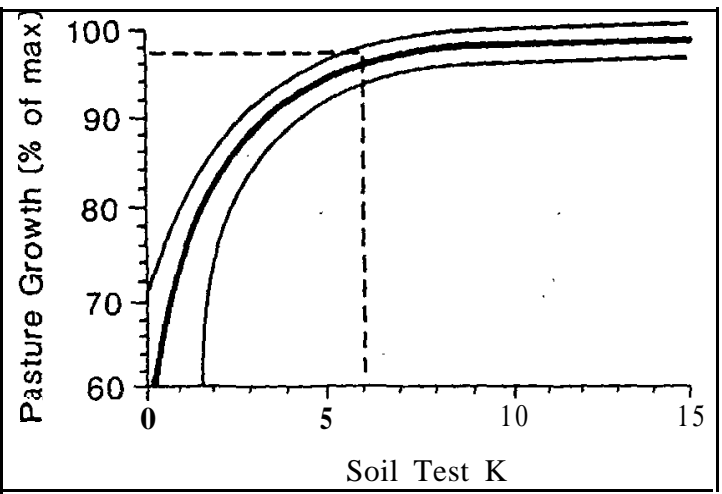

If reserve $\mathrm{K}$ levels are high enough, yellow-grey earth and recent soils are unlikely to require fertiliser $\mathrm{K}$ unless farmed under K-depleting systems such as pasture conservation or intensive dairy production. In these situation, K may not be supplied quickly enough from the clay minerals to satisfy pasture requirements.

\section{Trace elements}

Vitamin $B_{12}$ deficiency in lambs, Cu deficiency in cattle and deer and Se deficiency in sheep and cattle can occur on all North Otago soils and should be monitored in livers from slaughtered animals. Pasture deficiencies include Mo in clover and B in lucerne and swedes and these can be identified using leaf analysis.

\section{Maintaining soil fertility}

Once the optimum soil test is achieved on a farm, annual applications of nutrients are required to replace losses associated with the soil and animals and maintain this soil test. This rate of application is referred to as maintenance fertiliser.

Maintenance rates of nutrients can be estimated from pasture nutrient models as shown in booklets on fertiliser use (e.g., Morton et al. 1994). However, since the maintenance requirements vary from farm to farm, they are most accurately derived from monitoring of soil nutrient levels and interpreting them in relation to fertiliser nutrient applications. Such monitoring systems for flat to rolling land are described in the fertiliser booklets (e.g., Mortonetal. 1994). About five paddocks per farm are sampled annually in the same month each year and trends in soil nutrient levels monitored. Monitoring is being successfully used in practice on several dairy and sheep farms. For hill country, where variability in soil test levels will be greater, a joint Ravensdown-AgResearch sampling protocol has been developed. It has already been satisfactorily tested on farms and will soon be available for more general use.

\section{Economic basis for fertiliser application}

Farmers should and do make fertiliser decisions based on an economic rather than a production basis: On farms with higher financial returns (e.g., dairy, deer) applying more fertiliser to achieve and maintain a higher nutrient status and therefore higher pasture productivity is more profitable than on sheep and beef farms at current product prices. Since establishing optimum fertiliser policies based on economics is a complex process with many factors involved, AgResearch have adopted a modelling approach. From the database of previous trial results, the decision support model OUTLOOK $^{\mathrm{TM}}$ has been developed. For an individual farm, OUTLOOK ${ }^{\mathrm{TM}}$ will compare the long term economic returns from different $\mathrm{P}$ and $\mathrm{S}$ fertiliser policies.

Most of the production functions in OUTLOOK ${ }^{\mathrm{TM}}$ are based on $\mathrm{P}$ trials carried out under mowing and sheep grazing. There has been considerable debate regarding the relevance of these results to dairying, especially at high stocking rates. The only rates-of-P trials carried out in New Zealand under dairying have been at the Taranaki Agriculture Research Station (TARS). Results from the first trial (1986-1990) showed that for an initial Olsen $\mathrm{P}$ level of 27 , withholding $\mathrm{P}$ 
resulted in a reduction in milk solids production from Year 2 onwards at stocking rates of 3.7 and 4.3 cows/ha (Thomsonet al. 1992). In the second trial (1990-1993), $50 \mathrm{~kg} \mathrm{P} / \mathrm{ha} / \mathrm{yr}$ (average Olsen P 34) gave the best marginal economic return at 3.8 cows/ha (Thomson et al. 1992). The third trial (1994-1996) has shown that the economic optimum rate lies in the range of 2.5-1 00 $\mathrm{kg}$ P/ha (Olsen P 31-57), with no difference between 3.6 and 4.2 cows/ha,. OUTLOOK ${ }^{\mathrm{TM}}$ predicts that the most profitable policy for this situation is to omit fertiliser $\mathrm{P}$ for two years and then maintain an Olsen $\mathrm{P}$ of 27 with $48 \mathrm{~kg} \mathrm{P} / \mathrm{ha} / \mathrm{year}$. It can be seen that although there is some agreement between the trial results and OUTLOOK $^{\mathrm{TM}}$ predictions, there are also some contradictions, and further research is required. At present a trial is being set up at TARS to compare responses to $\mathrm{P}$ under grazing and mowing. Results from this will help clarify the validity of mowing trials to estimate responses to $\mathrm{P}$ under dairying.

One principle on which all the research workers involved agree is that dairy farmers can justify Olsen $\mathrm{P}$ levels greater than 30 only if pasture utilisation and milk solids production is very high $(>1000 \mathrm{~kg} / \mathrm{ha})$. Failure to follow this will result in unnecessarily high fertiliser costs, and less profit. The risk of $\mathrm{P}$ runoff losses to waterways, increasing weed growth and reducing water quality will also be greater.

\section{Conclusions}

1. The different physical properties of the soils of North Otago have a large effect on the farming system used and the manner.in.which the soils are managed.

2. In contrast, the chemical properties of most North Otago soils are similar. The relationships between soil $\mathrm{P}, \mathrm{K}$ and $\mathrm{S}$ levels and pasture production have been established for North Otago soils.

3. These relationships have been used to develop a decision support model (OUTLOOK ${ }^{\mathrm{TM}}$ ) to help decide on the most profitable fertiliser policy for a particular farm.

\section{REFERENCES}

Cornforth, I.S. 1980. Soil and Fertilisers: Soil analysis - interpretation. AgLink AST8, Wellington, New Zealand Ministry of Agriculture and Fisheries.

Jackson, B.L.J. 1985. A modified sodium tetraphenylboron method to the routine determination of reserve-potassium status of soil. New Zealand journal of experimental agriculture 13: 253-262.

Metherell, A.K.M.; McCall, D.G.; Woodward, S.J.R. 1995. OUTLOOK ${ }^{\mathrm{TM}}$ : a phosphorus fertiliser decision support model for grazed pastures. pp. 2439. In: Fertiliser requirements of grazed pasture and field crops. Macro and micro nutrients. (Eds. L.D. Currie \& P. Loganathan). Occasional Report No. 10, Fertiliser and Lime Research Centre, Massey University, Palmerston North.

Morton, J.D.; Roberts, A.H.C.; Edmeades, D.C. 1994. Fertiliser use on sheep and beef farms. FMRA/ AgResearch publication. 38pp.

Roberts, A.H.C.; Morton, J.D.; Edmeades, D.C. 1994. Fertiliser use on dairy farms. South Island and lower' North Island. DRC/AgResearch publication. 38pp. Saunders, W.H.M.; Cooper, D.M.; Sinclair, A.G. 1981. Soils and Fertilisers: Sulphur AgLink FPP 649 Wellington, New Zealand. Ministry of Agriculture and Fisheries.

Thomson, N.A.; McCallum, D.A.: Judd, T.G. 1993. A review of grazed studies in Taranaki evaluating phosphate fertiliser and dairy production. Dairy farming annual 45: 57-62.

Watkinson, J.H.; Perrott, K.W.; Thorrold, B.S. 1991.

- Relationships between the MAF pasture develop . ment index of soil and extractable organic sulphur. pp. 66-71. In: Soil and Plant Testing for Nutrient Deficiencies and Toxicities (Eds. R.E. White \& L.D. Currie) Occasional Report No. 5, Fertiliser and Lime Research Centre, Massey University, Palmerston North. 